\title{
Method of Determining and Assessment of Radon Exhalation Characteristics in Technogenic Objects
}

\author{
JurakulovA.R*, Muzafarov A.M, Urunov I.A, Allaberganova G.M, Husanov.Z.J, \\ Abdirakhmonov U.Sh \\ Navoi State Mining InstituteNavoi city, Uzbekistan
}

*Corresponding Author: Jurakulov A.R, Navoi State Mining Institute Navoi city, Uzbekistan

\begin{abstract}
This article presents the methods of determining radon exhalation and the results of assessment the characteristics of radon in technogenic objects. Studies conducted in recent years show that radon in terms of contribution to the total annual dose of radiation creates 20 times more contribution than the rest of the radionuclides of the uranium decay chain. Radon simultaneously belongs to the highest group A toxicity. For workers of category A (personnel), the values RAP and DKa of 222Rn (without decay products) are equal to $146 \mathrm{MBq} /$ year and $55.5 \mathrm{~Bq} / \mathrm{l}$, respectively. Radon accounts for more than $75 \%$ of the total annual dose of radiation, which on average receives the human body from technogenic factors of the environment, especially those working in the uranium technogenic objects.
\end{abstract}

Keywords: Radon exhalation, characteristics of radon behavior, total annual dose, individual annual dose, radioactive decay, radioactive series, uranium technogenic object.

\section{INTRODUCTION}

Among the radioactive radionuclides is one of the most dangerous. By entering the human body, radon contributes to the processes leading to cancer of various organs of a living being, especially the lungs. The decay of the nuclei of radon and its daughter radionuclides in the lungs causes a micro scald burn, since all the energy of $\alpha$-particles are absorbed almost at the decay point. Radon is also able to enter the body through intact skin. During the decay of radon, non-volatile radioactive products (isotopes $\mathrm{Po}, \mathrm{Bi}$ and $\mathrm{Pb}$ ) are formed, which are hardly excreted from the body.

In addition to natural sources, one of the main sources of radon is mill tailings of radioactive waste, sites of underground uranium leaching, storage sites of radioactive technological products, uranium oxide piercing workshops, sites of uranium productive solution processing, etc [1-6]. In the Republic of Uzbekistan, in 2000, the Law of the Republic of Uzbekistan "On Radiation Safety" was adopted and in 2006 the Norms of Radiation Safety (NRB-2006) and the Basic Sanitary Rules for Ensuring Radiation Safety (OSPORB-2006) which is populated on reduction of levels of irradiation of the population and production personnel from natural and technogenic sources of ionizing radiation [7]. On the basis of the abovementioned, the development of methods for determination and assessment the characteristics of radon exhalation in various technogenic objects is an urgent task of analytical chemistry, applied nuclear physics and radioecology [8-10].

\section{EXPERIMENTAL METHODS AND TECHNIQUES}

The measurements of radon exhalation were carried out by the measuring complex "Alpha plus» designed to determine the radon flux density from the soil surface, Rapid measurements and continuous monitoring of the volumetric activity - (VA) of radon-222 (222Rn) and the number of decays of Po (218ThA). The limit of permissible relative error at the measurements of VA $222 \mathrm{Rn}$ in soil, $\pm 30 \%$.

Measurement of the specific activity of the selected solid samples were carried out on a gamma radiometer "PROGRESS-GAMMA", which the margin of permissible basic relative error is $\pm 10 \%$.

\section{RESULTS AND DISCUSSION}

The amount of radon is determined by the "Alpha rad plus" complex based on the following reaction: 


$$
{ }^{222} \mathrm{Rn} \frac{\alpha}{3,8 \text { day }} .{ }^{214} \mathrm{~Pb} \frac{\beta}{26.8 \min }{ }^{214} \mathrm{Bi} \frac{\gamma}{19,8 \min }
$$

The basics of radiation monitoring and studying the behavior of radon is based on experimental studies of the physicochemical properties of controlled radionuclides. On the basis of the obtained results it is possible to draw a conclusion allowing to predict their migratory activity in objects of ecosystems.

The volumetric activity of radon in the atmospheric air of the mill tailing that comes out of the soil has been determined. The value concentration of radon in these soils is determined by the content of radionuclides in the uranium chain. Table 1 shows the results of measurement on the determination of VAR, specific activity of radionuclides, effective specific activity, and physical parameters of environment.

Table1.The results of measurements on determination of VAR, specific activity of radionuclides, effective specific activity and physical parameters of environment

\begin{tabular}{|c|c|c|c|c|c|c|c|c|}
\hline \multirow[b]{2}{*}{$\begin{array}{l}\text { № } \\
\text { s/n }\end{array}$} & \multirow[b]{2}{*}{$\begin{array}{l}\text { VA of radon } \\
\mathrm{mBq} / \mathrm{sm}^{2}\end{array}$} & \multirow[b]{2}{*}{$\begin{array}{c}\text { Air } \\
\text { temperature }^{0} C\end{array}$} & \multirow[b]{2}{*}{ Humidity\% } & \multirow[b]{2}{*}{$\begin{array}{r}\text { Pressure } \\
\mathrm{mm} . \mathrm{Hg}\end{array}$} & \multicolumn{4}{|c|}{ The specific activity in the soil } \\
\hline & & & & & $\begin{array}{c}\mathrm{K}^{40} \\
\mathrm{~Bq} / \mathrm{kg}\end{array}$ & $\begin{array}{c}\mathrm{K}^{40} \\
B q / k g\end{array}$ & $\begin{array}{c}\mathrm{K}^{40} \\
B q / k g\end{array}$ & $\begin{array}{c}\mathrm{K}^{40} \\
B q / k g\end{array}$ \\
\hline 1 & $46333 \pm 18533$ & 30 & 26 & 727 & 3896 & 18560 & 226 & 19188 \\
\hline 2 & $43614 \pm 17445$ & 30 & 37 & 728 & 3685 & 16985 & 216 & 17619 \\
\hline 3 & $30862 \pm 12628$ & 24 & 31 & 729 & 3149 & 16009 & 249 & 17180 \\
\hline 4 & $27846 \pm 16416$ & 28 & 33 & 729 & 2785 & 15500 & 185 & 15993 \\
\hline 5 & $26553 \pm 10621$ & 33 & 38 & 729 & 4158 & 13190 & 258 & 13902 \\
\hline 6 & $19843 \pm 79380$ & 31 & 23 & 730 & 3311 & 12680 & 207 & 13249 \\
\hline 7 & $19183 \pm 12418$ & 25 & 22 & 730 & 3256 & 12185 & 192 & 12689 \\
\hline 8 & $18782 \pm 76450$ & 23 & 29 & 730 & 1933 & 12091 & 142 & 12517 \\
\hline 9 & $14648 \pm 53430$ & 24 & 31 & 731 & 1704 & 11570 & 103 & 11958 \\
\hline 10 & $13448 \pm 10628$ & 28 & 30 & 732 & 2925 & 11249 & 185 & 11746 \\
\hline
\end{tabular}

From the results obtained in table 1 it can be seen that the VAR values vary from $13448 \mathrm{mBq} / \mathrm{cm} 2$ to $46333 \mathrm{mBq} / \mathrm{cm} 2$, the specific activity of radionuclides - K40 varies from $1704 \mathrm{~Bq} / \mathrm{kg}$ to $4158 \mathrm{~Bq} / \mathrm{kg}$, - Th232 varies from $103 \mathrm{~Bq} / \mathrm{kg}$ to $258 \mathrm{~Bq} / \mathrm{kg}$ and $-\mathrm{Ra} 226$ varies from $12680 \mathrm{~Bq} / \mathrm{kg}$ to $18670 \mathrm{~Bq} / \mathrm{kg}$. from $13902 \mathrm{~Bq} / \mathrm{kg}$ to $19280 \mathrm{~Bq} / \mathrm{kg}$. Effective specific activity - (Aeffec) varies from $13902 \mathrm{~Bq} / \mathrm{kg}$ to $19280 \mathrm{~Bq} / \mathrm{kg}$.

In addition, the VAR value is directly proportional depends on the specific activity of Ra226 and the effective specific activity - Aeffec.

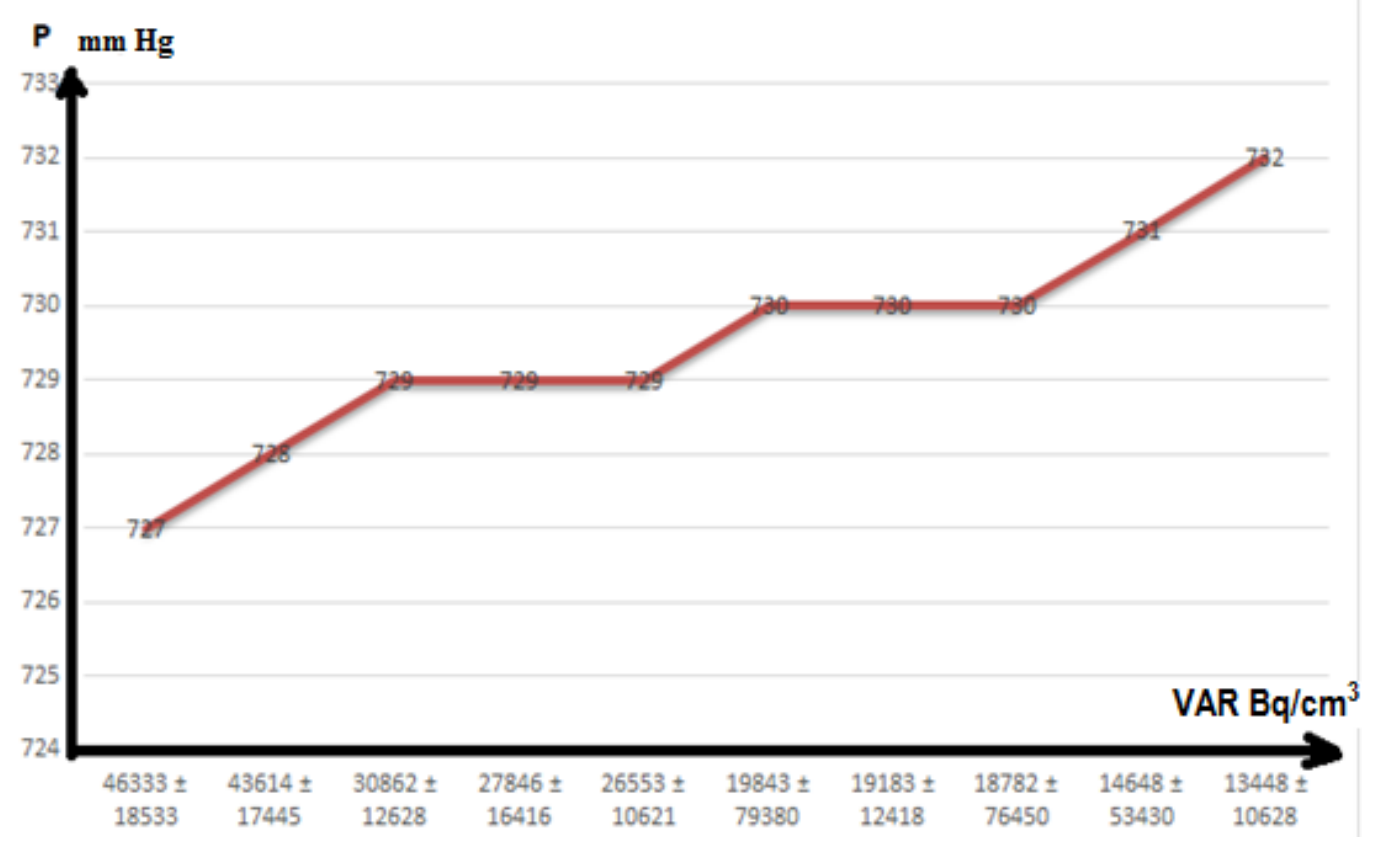

Figure1. shows the dependences of the VAR with the atmospheric pressure of the environment. 
As can be seen from figure 1 with increasing atmospheric pressure of the environment, the volumetric activity and in parallel radon exhalation decreases.

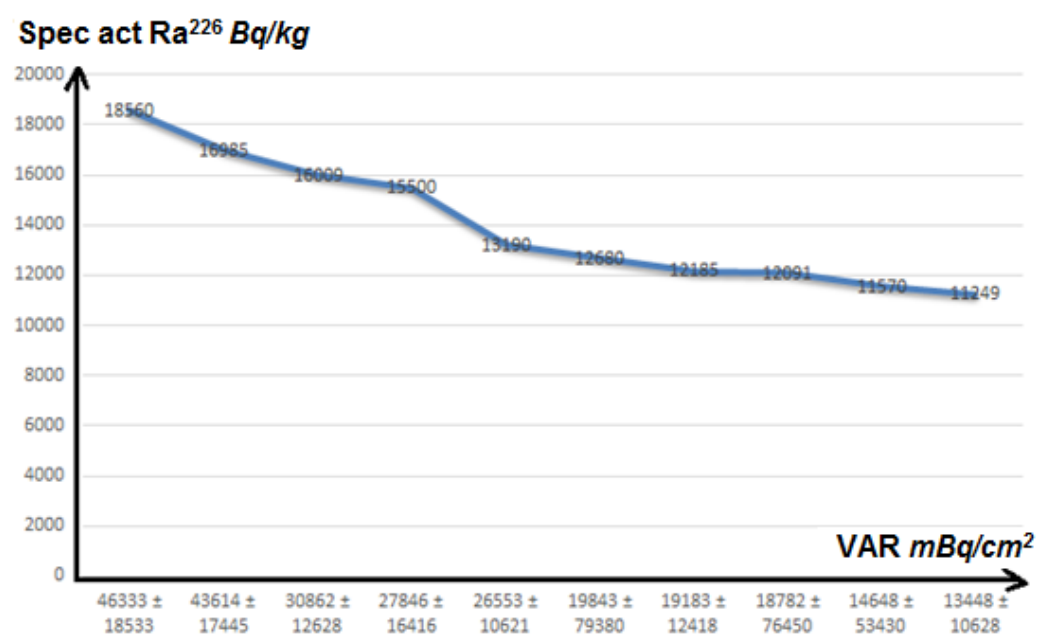

Figure2. Shows the dependences of the VAR depending on the specific activity of $R a^{226}$.

As can be seen from figure 2 with increasing specific activity of Ra226 in the soil and increases radon exhalation.

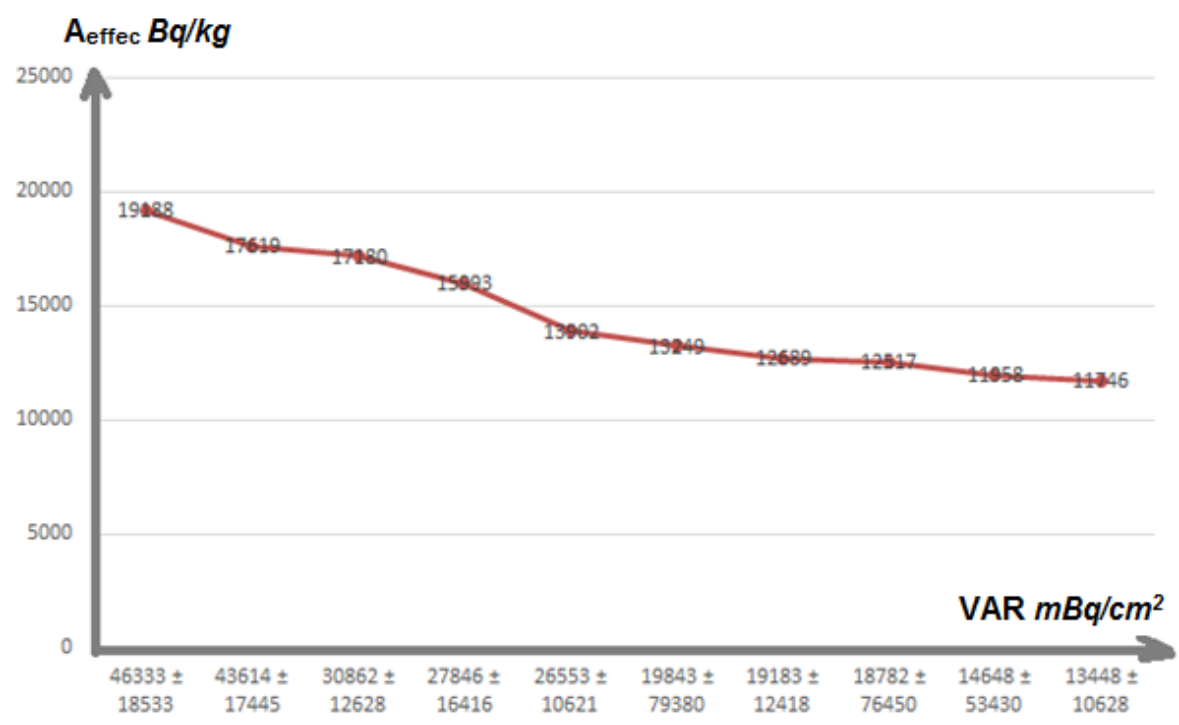

Figure3. Shows the dependence of the VAR on the specific effective activity- $A_{\text {effec. }}$

As can be seen from figure 3 with increasing specific effective activity - soil Aeffec and increases radon exhalation.

In addition to the above, it was found that radon emission from the soil has a seasonal character - the temperature increase causes the expansion of pores in the soil, and therefore increases the release of radon. In addition, the increase in temperature increases the evaporation of water, with which radon is carried into the surrounding space.

It has been determined that the VAR in the atmospheric air of production facilities is on average-from 4 to $212 \mathrm{~Bq} / \mathrm{m}^{3}$ and in the territories of the sanitary protection zone of production is-from 3 to 14 $\mathrm{Bq} / \mathrm{m}^{3}$.

Thus, as a result of the studies, changes in the OAR value were established, the specific activity values of radionuclides $-\mathrm{K}^{40}, \mathrm{Th}^{232}, \mathrm{Ra}^{226}$ were determined, the effective specific activity - (Aeff) was determined, and the dependences of the VAR on the values of the abovementioned quantities were constructed.

On the basis of the conducted researches in the long term planned actions for systematic control of radon behavior and carrying out calculation of total annual effective dose for the population living in 
the territory of influences of the industrial enterprise, the personnel working in them and improvement of a radio ecological condition in a zone of action of this enterprise can be developed.

\section{REFERENCES}

[1] Возжеников Г.С., Белышев Ю.В. Радиометрия и ядерная геофизика. Учебноепособие. Екатеринбург: 2006. - 418 с.

[2] Pravilov A.M. Radiometry in modern scientific experiments. -Wien.: Springer, 2011. -326 p.

[3] Бекман И. Радиоактивность, радионуклиды и радиация. - M.: PALMARIUM, 2014. - 498 c.

[4] Сапожников Ю. А. Радиоактивность окружающей среды. Теория и практика. - М.: БИНОМ, 2010. $286 \mathrm{c}$.

[5] Василенко О. И. Радиационная экология. -М.: Медицина, 2004. -216с.

[6] Пивоваров Ю.П., Михалев В.П. Радиационная экология. - М.: Академия, 2004. - 240 с.

[7] Санитарныенормы и правила радиационной безопасности СанПиН № 0193-06, (НРБ и ОСПОРБ 2006). Ташкент. - $86 \mathrm{c}$.

[8] Музафаров А., Темиров Б.Р., Саттаров Г.С. Оценка влияния техногенных факторов на экологию региона //Горный журнал Москва. 2013. №8.(1). - С.65-68.

[9] Музафаров А.М., Саттаров Г.С., Ослоповский С.А. Радиометрические исследования техногенных объектов //Цветные металлы. Москва. 2016. №2. - С. 15-18.

[10] Музафаров А.М., Темиров Б.Р., Саттаров Г.С. Экологических мониторинг техногенных факторов при добыче и переработке урана и золота // Экологический вестник. 2013. Вып №12.(152). - С.24-33.

Citation: JurakulovA.R, et.al, (2019)" Method of Determining and Assessment of Radon Exhalation Characteristics in Technogenic Objects ", Southeast Cameroon, International Journal of Mining Science (IJMS), 5(4), pp.35-38, DOI: http://dx.doi.org/10.20431/2454-9460.0504004

Copyright: (1) 2019 Authors. This is an open-access article distributed under the terms of the Creative Commons Attribution License, which permits unrestricted use, distribution, and reproduction in any medium, provided the original author and source are credited 